\title{
Temperature-dependent expression of the chromosomal $\beta$-lactamase gene in a strain of Pseudomonas aeruginosa
}

\author{
R. G. HEWINSON and W.W. NICHOLS*
}

\begin{abstract}
Nuffield Department of Pathology and Bacteriology, University of Oxford and *Regional Public Health Laboratory, Leve/ 6/7, John Radcliffe Hospital, Oxford, OX3 9DU
\end{abstract}

\begin{abstract}
Summary. A strain of Pseudomonas aeruginosa (3-Post) was resistant to cefsulodin and ceftazidime at $37^{\circ} \mathrm{C}$ but sensitive at $20^{\circ} \mathrm{C}$. Resistance was mediated by chromosomallyencoded $\beta$ lactamase which was synthesised at a high level during growth above $30^{\circ} \mathrm{C}$ but at a low, inducible level during growth below $27^{\circ} \mathrm{C}$.
\end{abstract}

\section{Introduction}

The regulation of chromosomally-encoded $\beta$ lactamase synthesis in Pseudomonas aeruginosa is an important area of study because resistance to "anti-pseudomonal" $\beta$-lactam antibiotics (Slack, 1981) can arise by mutation to constitutive synthesis (King et al., 1983; Williams et al., 1984). This class C $\beta$ lactamase (Ambler, 1980; Jaurin and Grundstrom, 1981; Knott-Hunziker et al., 1982) is normally inducible by $\beta$-lactam compounds (Nordström and Sykes, 1974). Induction of $\beta$-lactamase synthesis in Citrobacter freundi, apparently involves a positive control mechanism requiring two proteinencoding regulatory genes, termed $a m p R$ and $a m p D$ (Lindberg et al., 1985; Lindberg and Normark, 1986). Here we describe a mutant of $P$. aeruginosa that displays properties consistent with the operation of a similar control system.

\section{Materials and methods}

\section{Bacteria and sensitivity testing}

Organisms used were $P$. aeruginosa strain 3-Pre, and a cefsulodin-resistant mutant derived from it in vitro, strain 3-Post (Slack and Pitt, 1982; Slack et al., 1983). MIC values were determined on Isosensitest Agar (Oxoid) by the plate-incorporation method, with an inoculum of c. $10^{4} \mathrm{cfu} / \mathrm{spot}$. Disk tests were performed by Stokes's method on Isosensitest Agar.

\section{Growth and harvesting of bacteria}

Cells were grown in 80-ml volumes of the chemicallydefined medium ( $p \mathrm{H} \mathrm{7.8)}$ of Anwar et al. (1983) in 250-

Received 17 Dec. 1986; accepted 19 Jan. 1987. $\mathrm{ml}$ conical flasks with baffles, orbitally shaken at $170 \mathrm{rpm}$ (32-mm diameter of orbit). Cells were harvested at $E_{650}=0.2(0.098 \mathrm{mg}$ dry wt cells $/ \mathrm{ml})$ which represented the early exponential phase of growth. Induction of $\beta$ lactamase was achieved by adding benzyl penicillin $(200 \mathrm{mg} / \mathrm{L}$ final concentration) to the culture $2 \mathrm{~h}$ before harvesting the cells by centrifugation at $9400 \mathrm{~g}\left(r_{\mathrm{av}}\right.$ $7.0 \mathrm{~cm}$ ) for $10 \mathrm{~min}$ at $4^{\circ} \mathrm{C}$. The supernate was discarded. For suspensions to which penicillin had not been added, the pellet was used as the source of $\beta$ lactamase. For induced cells, the first pellet was washed by resuspension in $35 \mathrm{ml}$ of ice-cold $5 \mathrm{mM} \mathrm{MgCl}{ }_{2}-25 \mathrm{mM} \mathrm{3-(N-morphol-}$ ino)-propanesulphonic acid (MOPS) $(\mathrm{pH} 7.4)$ and recentrifugation as above. The pellet of washed bacteria was used as the source of $\beta$ lactamase from induced cells.

\section{Liberation of $\beta$ lactamase}

Pellets were subjected to three cycles of freezing and thawing, resuspended in ice-cold $5 \mathrm{mM} \mathrm{MgCl}_{2}-25 \mathrm{mM}$ MOPS ( $p \mathrm{H} \mathrm{7.4)}$ and subjected to a further freeze-thaw cycle. This treatment should release more than $90 \%$ of the $\beta$ lactamase of $P$. aeruginosa (Berks, 1977). A sample of the final freeze-thawed preparation of cells was centrifuged at $11000 \mathrm{~g}\left(r_{\mathrm{av} .} 9 \mathrm{~cm}\right)$ for $34 \mathrm{~min}$ at $4^{\circ} \mathrm{C}$. $\beta$ Lactamase activity was assayed in the supernate.

\section{Assays of $\beta$-lactamase activity}

The hydrolysis of cephalosporin $\mathrm{C}$ was monitored spectrophotometrically at $260 \mathrm{~nm}$ at $37^{\circ} \mathrm{C}$ in $5 \mathrm{~mm}$ $\mathrm{MgCl}_{2}-25 \mathrm{mM}$ MOPS ( $\left.p \mathrm{H} 7 \cdot 4\right)$. The kinetic parameters, $K_{\mathrm{m}}$ and specific $V_{\max }$, were determined by automated (Nichols and Hewinson, 1987) half-time analysis of reaction progress curves (Wharton and Szawelski, 1982).

\section{Results}

As defined by disk-diffusion tests, $P$. aeruginosa 3-Post was sensitive to cefsulodin and ceftazidime 
at $20^{\circ} \mathrm{C}$ but was resistant at $37^{\circ} \mathrm{C}$. P. aeruginosa 3Pre, from which strain 3-Post was derived (Slack and Pitt, 1982), was sensitive to both antibiotics at both temperatures. The MIC of cefsulodin at $37^{\circ} \mathrm{C}$ for strain 3-Pre was $1.70-1.75 \mathrm{mg} / \mathrm{L}$, and for strain 3-Post was $17-18 \mathrm{mg} / \mathrm{L}$. However, at $17^{\circ} \mathrm{C}$ the MIC of cefsulodin for both strains was $0.25-0.5 \mathrm{mg} / \mathrm{L}$.

The table shows the effects of growth temperature on $\beta$-lactamase synthesis in the two strains. The $\beta$ lactamase of strain 3-Post was synthesised at an elevated level at $37^{\circ} \mathrm{C}$ but at a 14 -fold lower level at $21^{\circ} \mathrm{C}$. The lower basal level $(480 \mathrm{nmol} / \mathrm{min} / \mathrm{mg}$ dry wt) was higher than that of the parent strain, 3-Pre, at either temperature ( 24 and $72 \mathrm{nmol} / \mathrm{min} / \mathrm{mg}$ dry wt at $22^{\circ} \mathrm{C}$ and $37^{\circ} \mathrm{C}$ respectively). When strain 3Post was grown at the lower temperature, $\beta$ lactamase synthesis was inducible.

The change from low-level to high-level $\beta$ lactamase synthesis in strain 3-Post occurred between the growth temperatures $27^{\circ} \mathrm{C}$ and $29 \cdot 5^{\circ} \mathrm{C}$ (figure). The amount of $\beta$ lactamase synthesised in strain 3-Post decreased with rising temperature above $30^{\circ} \mathrm{C}$.

\section{Discussion}

The different cefsulodin and ceftazidime sensitivities of $P$. aeruginosa 3-Post at room temperature and at $37^{\circ} \mathrm{C}$ were, at least partly, determined by the levels of $\beta$-lactamase synthesised at these two temperatures. We suggest that a protein involved in regulating $\beta$-lactamase synthesis is thermolabile in strain 3-Post, and that this explains the sharpness of the temperature dependence of the cell complement of $\beta$-lactamase (figure).

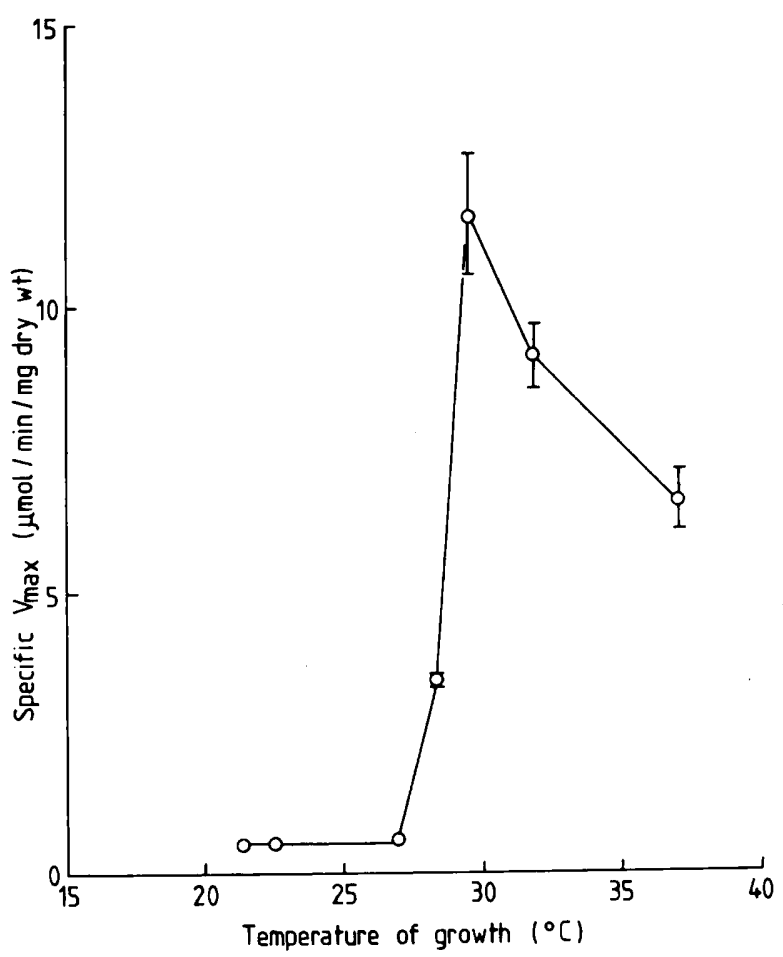

Figure. $\beta$-Lactamase activities of extracts of $P$. aeruginosa 3-Post grown at different temperatures. Assays of cephalosporin $C$ hydrolysis were all made at $37^{\circ} \mathrm{C}$. The enzyme kinetic parameter, specific $V_{\max }$, was determined for each point by half-time analysis of reaction progress curves. Error bars show \pm 2 SEM determined from four to six replicate measurements. At $27^{\circ} \mathrm{C}$ and below, error bars were too small to draw.

In $C$. freundi there is a regulatory protein (the $a m p R$ gene product) that represses synthesis of the $\beta$ lactamase about $2 \cdot 5$-fold but that apparently acts as an activator of transcription of the $\beta$-lactamase

Table. $\beta$-Lactamase activities (substrate cephalosporin C) assayed at $37^{\circ} \mathrm{C}$

\begin{tabular}{|c|c|c|c|c|c|c|c|}
\hline \multirow[b]{2}{*}{ Strain } & \multirow{2}{*}{$\begin{array}{c}\text { Mean growth } \\
\text { temperature } \\
\left({ }^{\circ} \mathrm{C}\right)\end{array}$} & \multirow{2}{*}{$\begin{array}{l}\text { Induced } * / \\
\text { uninduced }\end{array}$} & \multicolumn{2}{|c|}{$\mathbf{K}_{\mathrm{m}}(\mu \mathrm{M})$} & \multicolumn{2}{|c|}{$\begin{array}{c}\text { Specific } V_{\max } \\
\text { (nmol/min/mg } \\
\text { dry wt) }\end{array}$} & \multirow[b]{2}{*}{$\mathrm{n}$} \\
\hline & & & mean & SEM & mean & SEM & \\
\hline \multirow[t]{2}{*}{ 3-Pre } & 21.9 & uninduced & $18 \cdot 2$ & 1.8 & 24 & 2 & 3 \\
\hline & & induced & $25 \cdot 5$ & $2 \cdot 6$ & 1260 & 200 & 6 \\
\hline \multirow[t]{2}{*}{ 3-Pre } & 37.0 & uninduced & $20 \cdot 0$ & $1 \cdot 1$ & 72 & 3 & 4 \\
\hline & & induced & 18.9 & $1 \cdot 3$ & 1240 & 40 & 4 \\
\hline \multirow[t]{2}{*}{ 3-Post } & $21 \cdot 3$ & uninduced $\dagger$ & $19 \cdot 4$ & 1.0 & 480 & 20 & 5 \\
\hline & & induced & $17 \cdot 2$ & $0 \cdot 7$ & 1490 & 40 & 5 \\
\hline 3-Post & $37 \cdot 0$ & uninduced $\dagger$ & $21 \cdot 3$ & $1 \cdot 2$ & 6560 & 240 & 4 \\
\hline
\end{tabular}

\footnotetext{
* $\beta$ Lactamase was induced by the addition of benzyl penicillin $(200 \mathrm{mg} / \mathrm{L})$ to the culture $2 \mathrm{~h}$ before harvesting the cells.

$\dagger$ The data for uninduced cells of 3-Post are included in the figure.
} 
$(a m p C)$ gene on induction (Lindberg et al., 1985; Lindberg and Normark, 1986). Mutations to constitutive synthesis map outside the $a m p R$-ampC region but the constitutive phenotype is only observed in the presence of a functional $a m p R$ gene product (Lindberg et al., 1985). The results of the experiments reported in the present communication are consistent with this system also operating in $P$. aeruginosa because a mutant of $C$. freundi has been isolated which demonstrates temperature-sensitive expression of $\beta$ lactamase with a phenotype that is very similar to that of strain 3-Post (Sawai et al., 1977).

Constitutive synthesis of the class $C \beta$ lactamase

\section{REFERENCES}

Ambler R P 1980 The structure of $\beta$-lactamases. Philosophical Transactions of the Royal Society of London Series B 289: 321-331.

Anwar H, Lambert P A, Brown M R W 1983 Effect of divalent metal ions on the production of outer membrane protein $\mathrm{H}_{2}$ in mucoid and non-mucoid strains of Pseudomonas aeruginosa. FEMS Microbiology Letters 16 : 247-250.

Berks M 1977 Studies on $\beta$-lactamases from Pseudomonas aeruginosa. DPhil Thesis, University of Oxford.

Hewinson R G, Slack M P E, Nichols W W 1985 A quantitative study of beta-lactamase-mediated trapping $v$ hydrolysis in cefsulodin-resistant Pseudomonas aeruginosa. In: Ishigami J (ed) Recent advances in chemotherapy, antimicrobial section. University of Tokyo Press, Tokyo, pp 365-366.

Jaurin B, Grundström T 1981 ampC cephalosporinase of Escherichia coli $\mathrm{K}-12$ has a different evolutionary origin from that of $\beta$-lactamases of the penicillinase type. Proceedings of the National Academy of Sciences of the USA 78: 4897-4901.

King A, Shannon K, Eykyn S, Phillips I 1983 Reduced sensitivity to $\beta$-lactam antibiotics arising during ceftazidime treatment of Pseudomonas aeruginosa infections. Journal of Antimicrobial Chemotherapy 12: 363-370.

Knott-Hunziker V, Petursson S, Jayatilake G S, Waley S G, Jaurin B, Grundström T 1982. Active sites of $\beta$-lactamases. The chromosomal $\beta$-lactamases of Pseudomonas aeruginosa and Escherichia coli. Biochemical Journal 201 : 621-627.

Lindberg F, Westman L, Normark S 1985 Regulatory components in Citrobacter freundii ampC $\beta$-lactamase induction. Proceedings of the National Academy of Sciences of the USA 82: $4620-4624$.

Lindberg F, Normark S 1986 Contribution of chromosomal $\beta$ lactamases to $\beta$-lactam resistance in enterobacteria. Reviews of Infectious Diseases 8 Suppl 3: S292-S304.

Livermore D M 1985 Do $\beta$-lactamases 'trap' cephalosporins? Journal of Antimicrobial Chemotherapy 15: 511-514. in $P$. aeruginosa confers resistance to cefsulodin and ceftazidime whereas basal, but inducible, synthesis does not (Livermore, 1986). The mechanism of this type of resistance has been the subject of debate as to whether hydrolysis (Livermore, 1985) or nonhydrolytic "trapping" (Sanders, 1984) by periplasmic $\beta$ lactamase is responsible. The mechanism of resistance of strain 3-Post to cefsulodin at $37^{\circ} \mathrm{C}$ could be best explained by $\beta$-lactamase-catalysed hydrolysis of the antibiotic within the periplasmic space (Hewinson et al., 1985).

We thank the EPA Research Trust for a scholarship for training in research methods for R.G.H.

Livermore D M 1986 Class I $\beta$-lactamase expression in Pseudomonas aeruginosa and cephalosporin resistance. Lancet 1 : 450.

Nichols W W, Hewinson R G 1987 Rapid and automated measurement of $K_{\mathrm{m}}$ and specific $V_{\max }$ values of $\beta$-lactamases in bacterial extracts. Journal of Antimicrobial Chemotherapy 19: $285-295$.

Nordström K, Sykes R B 1974 Induction kinetics of $\beta$-lactamase biosynthesis in Pseudomonas aeruginosa. Antimicrobial Agents and Chemotherapy 6: 734-740.

Sanders C C 1984 Inducible $\beta$-lactamases and non-hydrolytic resistance mechanisms. Journal of Antimicrobial Chemotherapy 13: 1-3.

Sawai T, Nakajima S, Morohoshi T, Yamagishi S 1977 Thermolabile repression of cephalosporinase synthesis in Citrobacter freundii. Microbiology and Immunology 21 : 631 638.

Slack M P E 1981 Antipseudomonal $\beta$-lactams. Journal of Antimicrobial Chemotherapy 8: 165-170.

Slack M P E, Pitt T L 1982 Characterization of cefsulodinresistant variants of Pseudomonas aeruginosa. Journal of Antimicrobial Chemotherapy 9: 111-117.

Slack M P E, Nichols W W, West C 1983 Studies on the mechanisms of cefsulodin resistance in Pseudomonas aeruginosa. In: Spitzy K H, Karrer K (eds) Proceedings of the thirteenth international congress of chemotherapy, Part 87: Antibiotic resistance in vitro. Verlag H. Egermann, Vienna, pp 40-43.

Wharton C W, Szawelski R J 1982 Half-time analysis of the integrated Michaelis equation. Simulation and use of the half-time plot and its direct linear variant in the analysis of some $\alpha$-chymotrypsin-, papain- and fumarase-catalysed reactions. Biochemical Journal 203: 351-360.

Williams R J, Livermore D M, Lindridge M A, Said A A, Williams J D 1984 Mechanisms of beta-lactam resistance in British isolates of Pseudomonas aeruginosa. Journal of Medical Microbiology 17: 283-293. 